\title{
Acid production as a Limiting Factor during the Aerobic Biological Pre- Treatment of Confectionary Wastewaters
}

\section{Christian Drakides and Meiling Lay-Son*}

Hydrosciences Laboratory, Université Montpellier II, 34095 Montpellier cedex 05, France

\begin{abstract}
The treatment of confectionary wastewaters by a biological aerobic treatment plant encountered strong failures when wastewaters concentration exceeded $30 \mathrm{~g} / \mathrm{l}$ of chemical oxygen demand (COD), although the COD inlet flow remained under design specifications. Treatment performances stayed under $50 \%$, and strong acid production and Hydrogen potential drop lead to heavy corrosion of equipments.

During a laboratory scale study using the same organic load, with residence times ranging from 1 to 15 days, Hydrogen potential $(\mathrm{pH})$ drop proved to be caused mainly by aerobic production of organic acids from sugars, leading thus to an auto-inhibiting process. The study demonstrated the influence of $\mathrm{pH}$, acids and aeration rate upon key parameters as respiration rates and degradation kinetics. A reduction of 30 to $35 \mathrm{~g} / \mathrm{l}$ of COD was obtained in laboratory scale reactors with $\mathrm{pH}$ and oxygen control.
\end{abstract}

A comparison between the laboratory scale reactors and the full scale plant was made by measuring in the reactors the clean water oxygenation transfer rates and comparing its values to the data issuing from the plant.

Compared to the data issuing from the full-scale wastewater treatment plant, the results of this study allowed giving recommendations for its upgrade.

Keywords: Biological treatment; Chemical oxygen demand; Confectionary wastewaters; Organic acids; Oxygenation transfer rates; $\mathrm{pH}$

\section{Introduction}

Wastewater concentration in confectionary factories may vary widely depending upon the products and the processes. As the main stream of wastewater issues from the washings, a consequence of water savings policies is the production of a relatively small volume of wastewater with a high organic content (primarily sugars). This high organic content is represented by high levels of chemical Oxygen demand (COD) and biological oxygen demand (BOD). Consequently, this wastewater is normally easily amenable to biological degradation if the required nutrients are added in proportion to the concentrations of the wastewater organic compounds [1].

Among the aerobic biological wastewater treatment processes the most commonly used is the activated sludge one [2]. If the treated water can be discharged to an existing domestic sewer connected to a wastewater treatment plants facility (WWTP), an aerobic high-rate pre-treatment may be chosen to avoid the investment in a separate complete WWTP and to minimize operation costs. In the present confectionary wastewater treatment case, a COD volumetric load of 6 $\mathrm{kg} \mathrm{COD} / \mathrm{m}^{3} / \mathrm{d}$ was designed to obtain a COD degradation rate limited to $70 \%$, normally allowing the discharge of the pre-treated effluent to the sewer. The maximum corresponding allowed concentrations were of $61 \mathrm{~g} / \mathrm{l}$ for the influent and of $18.75 \mathrm{~g} / \mathrm{l}$ for the effluent. Nevertheless, after a few months of operation, the $\mathrm{pH}$ in the tanks fell under 4.8 units and performances under $50 \%$. After one year, the aeration equipments and tanks were out of work because of corrosion, and the WWTP was emptied.

Although the inhibition of anaerobic methanisation by acetate has been described early [3], little information has been published concerning acetate or volatile fatty acids (VFA) inhibition during aerobic processes. Considering this latter parameter, Adamse [4] studied the effect of aeration rate and $\mathrm{pH}$ on response of dairy waste activated sludge, Orhon et al. [1] the biological treatability of confectionary wastewaters by respirometric techniques, Ugwanyi et al. [5] the inhibition of thermophilic aerobic treatment of agricultural wastes, and De Anda et al. [6] the efficiency of protein production with E. coli.

In aerobic processes, oxygen transfer is often the rate-limiting step for the degradation kinetics, due to the low solubility of oxygen in aqueous solutions, and the correct determination of operational parameters is a crucial step in the design, operation and scale-up of bioreactors $[7,8]$.

This paper reports a laboratory study of the biological pretreatment of these high strength confectionary wastewaters by means of a high-load activated sludge process. Design parameters have been determined, and their effects upon $\mathrm{pH}$, aeration rate and VFA production have been discussed.

\section{Materials and Methods}

\section{Experimental setup}

Experiments were carried out in laboratory using two reactors, each consisting of a highly mixed aerated tank connected to a clarifier. Each reactor was equipped with two peristaltic pumps, one for feeding wastewater and one for recycling sludge from the clarifier, and with a variable number of aerators and air pumps. Reactor 1 had a $3 \mathrm{~L}$ tank volume and reactor 2 had a $6 \mathrm{~L}$ volume.

Reactor hydraulics was close to perfect mixing, and effluent concentration represented the concentration in aeration tanks.

*Corresponding author: Meiling Lay-Son, Hydrosciences Laboratory, Université Montpellier II, 34095 Montpellier cedex 05, France; Tel: 33 467143624; Fax: 33 467144774; E-mail: mey8@yahoo.com

Received January 11, 2013; Accepted May 22, 2013; Published June 02, 2013

Citation: Drakides C, Lay-Son M (2013) Acid production as a Limiting Factor during the Aerobic Biological Pre-Treatment of Confectionary Wastewaters. J Civil Environ Eng 3: 128. doi:10.4172/2165-784X.1000128

Copyright: (C) 2013 Drakides C, et al. This is an open-access article distributed under the terms of the Creative Commons Attribution License, which permits unrestricted use, distribution, and reproduction in any medium, provided the original author and source are credited. 
Temperature was maintained at $25 \pm 0.5^{\circ} \mathrm{C}$ for the two reactors, $\mathrm{pH}$ was monitored and adjusted in the reactors by $\mathrm{NaOH}$ or $\mathrm{HCl}$ addition, and dissolved oxygen was measured daily.

Mean water residence time (MWRT) was calculated measuring the daily outlet flow, and was kept between 1 and 15 days.

For each parameter condition set, an adaptation time of at least three times the current residence time was allowed before analytical results were considered representative of steady-state conditions.

\section{Operational procedure}

The feed wastewater was recuperated once monthly directly from a confectionary WWTP (HARIBO Uzes, France). This wastewater is characterized by high levels of sugars. The characteristics of the influent were variable along time, as the sugars were rapidly transformed in ethanol and acetic acid under storage conditions. Consequently, wastewater was keep freezed at $-18^{\circ} \mathrm{C}$ until feeding the reactors, to preserve its initial characteristics. Table 1 shows the concentrations range for the influent fed to the reactors (most of time undiluted).

Feeding was divided in eight batches per day, one every three hours, to represent the wastewaters treatment plant (WWTP) conditions, where wastewaters are collected in a tank in the confectionary and pumped to the WWTP once this tank is full.

Each reactor was inoculated initially with sludge collected from the confectionary WWTP.

The same operational conditions were tested in the reactors, which differed mainly with their aeration conditions.

MWRTs were gradually reduced at the end of experiments from 10 days to 1 , diluting the effluent proportionally to the inverse of residence time. This allowed the reactors to work at a nearly constant organic load ( 0.6 to $1.4 \mathrm{~g}$ COD/gMLSS/d), whereas varying actual COD concentrations in the reactors (suspended solids of pilot mixed liquor were kept around $5 \mathrm{~g} / \mathrm{l}$ value, close to WWTP values).

The effect of $\mathrm{pH}$ upon respiration and degradation kinetics was studied using the respirometric method by measuring the oxygen uptake as indicator of biodegradation. This method is described in 4.4.

Oxygenation rates were adjusted by varying the number of air pumps and porous diffusers in the tanks.

\section{Analytical methods}

Influent and effluent samples were filtered through 0.2 um cellulose acetate filters (Sartorius stedim, Germany) and preserved by sodium azide $(2.5 \mathrm{mM})$ before analyses of sugars (glucose, fructose and sucrose) and organic acids (acetic, lactic, propionic, etc).

Glucose, fructose and sucrose concentrations were determined using high-performance anion exchange chromatography (HPAEC), on a Carbopac PA-1 analytical column $(4 \times 250 \mathrm{~mm})$. Detection was performed with a pulsed amperometric ED50 detector (Dionex Corp., Sunnyvale, CA). Twenty five microliters of sample were injected. Each carbohydrate concentration was established after integration of respective areas (Chromeleon management system (Dionex)) and comparison with standard curves obtained with all relevant sugar standards (Sigma). The elution was achieved isocratically with $18 \mathrm{mM}$ $\mathrm{NaOH}$ at a flow rate of $1 \mathrm{ml} / \mathrm{min}$.
Organic acids were analysed by high-performance liquid chromatography (HPLC) upon centrifuged (10 min, 10,000 g at $\left.4^{\circ} \mathrm{C}\right)$ and deproteinized samples. Protein removal was carried out using $\mathrm{Ba}(\mathrm{OH})_{2}-\mathrm{ZnSO}_{4}, 7 \mathrm{H}_{2} \mathrm{O}$ method of Slein. The HPLC system (Agilent 1100, Agilent Technology) was fitted with two columns (Resex ROA $300 \times 7.8 \mathrm{~mm}$, Phenomenex) mounted in serial assembly in an oven thermostated at $50^{\circ} \mathrm{C}$. Columns were eluted at $0.7 \mathrm{~mL} / \mathrm{min}$ by a solution of $2 \mathrm{mM} \mathrm{H}_{2} \mathrm{SO}_{4}$ in ultra pure water. A refractometer (RID G1362A) was used as detector.

Acetic and lactic acids were also measured using specific enzymatic test kits (Megazyme, Ireland).

Total acidity, expressed under acetic acid which was the largely dominant form, was measured by acid-base titration. Additionally, the computational program CURTIPOT $^{1}$, was used to generate potentiometric titration curves for the parameter set chosen in each simulation, allowing to take into account the other acid-base constituents of the waters.

COD was measured using a photometric method for small-sample rapid dichromate oxidation (HACH DR2010 spectrophotometer and digester, and COD Vials CHEMetrics reagent).

Mixed liquor total suspended solids (MLSS) in the reactors were measured by filtration through Whatman GF/C filters followed by drying and weighing with a Precisa 410 AM-FR balance.

$\mathrm{pH}$ and Dissolved oxygen concentration (DO) were measured daily in the reactors using $\mathrm{pH}$ meters (EUTECH Instruments, IQ Scientific Instruments) and standard DO meters (WTW Microprocessor Oximeter, Ponselle $\mathrm{O}_{2} \mathrm{~W}$ ).

(Note: special care had to be given to Oxygen and $\mathrm{pH}$ probes choice and maintenance. High organic acids and sulfid-riche proteins concentrations leaded to rapid and irreversible probes deterioration and to high measurement errors with some Oxygen probes too sensitive to undissociated organic acids interference)

\section{Respirometry}

Respirometric techniques were used in preliminary experiments for the evaluation of the influence of $\mathrm{pH}$ on the degradation kinetics through estimation of $\mathrm{V}_{\max }$ and $\mathrm{K}_{\mathrm{M}}$ Michaelis-Menten constants. Batch reactors containing $250 \mathrm{ml}$ volume of mixed liquor sampled in the reactors were saturated with air and DO consumption followed using the same standard probes used to monitor DO in the reactors. Temperature was maintained at $20 \pm 0.5^{\circ} \mathrm{C}$. Specific Oxygen uptake rate (SPOUR) was calculated by dividing the slope of the best-fit regression line of the DO decrease along time by the MLSS measured of each sample. $\mathrm{pH}$ and initial concentrations of added substrates (sugars or acids) were fixed for each experiment.

\section{Assessment of oxygenation rates $\left(k_{L} a\right)$}

In order to study the effect of aeration on sugars and acids degradation kinetics, the volumetric Oxygen mass transfer coefficients $\left(k_{\mathrm{L}} \mathrm{a}\right)$ of the reactors were measured for aeration configurations differing by the number of air diffusers and the volumetric airflow. These configurations allowed the pilot plants to work with measured $\mathrm{k}_{\mathrm{L}}$ a values ranging from $1.5 \times 0^{-3} / \mathrm{s}$ to $9.8 \times 10^{-3} / \mathrm{s}$.

\begin{tabular}{|c|c|c|c|c|c|c|c|c|}
\hline Parameters & COD & BOD & MLSS & Glucose & Fructose & Sucrose & Acetic Acid & Lactic Acid \\
\hline $\mathrm{g} / \mathrm{l}$ & $25-62$ & $4-34$ & $0.1-2.8$ & $0-9.2$ & $0-6.3$ & $0.3-21.3$ & $0-6.5$ \\
\hline
\end{tabular}

Table 1: Concentration range of the influent fed to two reactors. 
Determination of $\mathrm{k}_{\mathrm{L}} \mathrm{a}$ in the reactors was necessary to quantify aeration efficiency and to evaluate the effects of the operating variables on the actual supply of dissolved Oxygen to the MLSS bacteria. Mass balance for the dissolved oxygen in a well-mixed liquid phase can be established, in the absence of biomass or with non-respiring cells, as Equation 1:

$$
\frac{d C}{d t}=k_{L} a\left(C_{s}-C\right)
$$

where $\mathrm{dC} / \mathrm{dt}$ is the accumulation Oxygen rate in the liquid phase, $\mathrm{C}$ the actual oxygen concentration and Cs the saturation concentration.

In this study, the $\mathrm{k}_{\mathrm{L}}$ a values for the different configurations were determined using the method described by Déronzier et al. [7], or sodium sulfite addition method in the aeration tank under standard conditions, i.e. reactors filled with clean (tap) water, no biomass, initial DO $=0 \mathrm{mg} / \mathrm{l}$. The Oxygen transfer estimation was based on the measurement of dissolved oxygen concentration in the liquid during the absorption of oxygen in the solution. DO increase under constant aeration was monitored using two standard dissolved $\mathrm{O}_{2}$ probes [9].

The $\mathrm{k}_{\mathrm{L}} \mathrm{a}$ was then calculated from the obtained regression curve using a least-squares approximation method written under EXCEL ${ }^{\circledR}$.

One main shortcut of the $\mathrm{k}_{\mathrm{L}}$ a determination method is that the measure is done using tap water, and the result reported to reference conditions (DO of $0 \mathrm{mg} / \mathrm{l}, \mathrm{T}^{\circ}$ of $10^{\circ} \mathrm{C}$ ). During real wastewater treatment, presence of biomass and soluble compounds may strongly affect the dissolution of Oxygen, lowering the $\mathrm{k}_{\mathrm{L}}$ a by an unknown factor (alpha), often estimated around 0.7 [3]. But here, high concentrations of sugars, acids and proteins may have much more incidence and the standard $\mathrm{k}_{\mathrm{L}}$ a cannot be extrapolated to real conditions. Nevertheless, as laboratory experiments were conducted with the same wastewaters and in the same conditions of $\mathrm{pH}$ and $\mathrm{T}^{\circ}$ as in real installations, the clean water $k_{\mathrm{L}} \mathrm{a}$ found in the laboratory can be usefully compared with the data given by the furnishers of the industrial aeration equipment and also obtained using tap water assays.

Once known the $\mathrm{k}_{\mathrm{L}} \mathrm{a}$, the Oxygen transfert rate (OTR) in clean water for a given Oxygen concentration $\mathrm{C}$ can be estimated through equation 2:

$$
\mathrm{OTR}=\mathrm{k}_{\mathrm{L}} \mathrm{a}^{\star}(\mathrm{Cs}-\mathrm{C})
$$

Under constant $\mathrm{k}_{\mathrm{L}}$ a conditions, OTR is compensed by biological respiration and any variation of biological activity leads to a variation of the measured $\mathrm{C}$, which comes as a good indicator of activity or inhibition.

As the same substrate and saline concentrations, temperature or $\mathrm{pH}$ were used in the pilots as well as in the real plant, the measured DO in the pilots may be used to characterize the aerating conditions leading to acids production or degradation, and by comparing the OTR values measured in the pilots and given for the real plant, to characterize the aerating conditions prevailing in the real plant and their influence upon treatment inhibition.

\section{Kinetic models}

The Michaelis-Menten equation (Equation 3) is typically used to represent degradation kinetics when a substrate is not inhibitory for the enzymatic activity $[2,10,3]$. It was used here to represent the sugars and acid degradation rates and also the respiration rates in the presence of pure glucose and a mixture of sugars.

$$
\frac{d S}{d t}=\frac{d P}{d t}=V \max \times\left(\frac{S}{K s+S}\right)
$$

Where $\mathrm{V}_{\max }$ is the maximum velocity of the enzyme process, $\mathrm{K}_{\mathrm{s}}$ the Michaelis-Menten constant, $\mathrm{dS} / \mathrm{dt}$ the degradation rate of the substrate, $\mathrm{dP} / \mathrm{dt}$ the formation rate of the product and $\mathrm{S}$ the concentration of substrate.

Parameter optimisation was made for $\mathrm{V}_{\max }$ and $\mathrm{K}_{\mathrm{s}}$ with a leastsquares method to allow a best fit of the kinetic model to experimental data.

\section{Results and Discussion}

The activated sludge reactors follow-up was carried on five hundred ten days. Preliminary studies were made to determinate the influence of $\mathrm{pH}$ upon degradation kinetics and the optimal $\mathrm{pH}$ interval.

\section{Inhibition caused by extreme $\mathrm{pH}$ values}

When the graph was plotted of the SPOUR measured for the mixed liquor of the reactors versus $\mathrm{pH}$, the SPOUR never fall to low values for $\mathrm{pH}$ ranging from 5.5 to 6.5 units. Inhibition occurred frequently under $\mathrm{pH}$ value of 5.7, and less frequently over $\mathrm{pH}$ value of 6.5 (Figure1).

This result was confirmed by $\mathrm{pH}$ and DOES monitoring of the two reactors. A plot of these two parameters shows that with a constant aeration rate, $\mathrm{DO}$ fall to values close of $0 \mathrm{mg} / \mathrm{l}$ only for $\mathrm{pH}$ values ranging from 6 to 7.5, indicating high respiratory activity of the MLSS bacteria. It was therefore concluded that values of $\mathrm{pH}$ less than 5 or 6 (according to the pilot aeration) or greater than 8 led to respiratory inhibition and DO increase (Figure 2).

\section{Respirometric evaluation and kinetic coefficients}

SPOUR measurement was also made using the mixed liquor from pilot plants and known added concentrations of mixture of sugars and pure glucose to evaluate the respiratory rate. Results are shown figures 3 and Figure 4.

a) Substrate: $50 \%$ glucose and $50 \%$ sucrose, $\mathrm{pH}=5.5$

The Michaelis-Menten equation was used as mentioned above. For this experiment, the best adjusted parameters were found to be $\mathrm{K}_{\mathrm{s}}=1.58$ $\mathrm{g} / \mathrm{l}$ and $\mathrm{V}_{\max }=0.046 \mathrm{mg} \mathrm{O}_{2} / \mathrm{min} / \mathrm{gMLSS}$.

b) substrate: $100 \%$ glucose, $\mathrm{pH}=5.8$

The same adjustment of a Michaelis-Menten equation gaves values of $\mathrm{Vmax}=0.101 \mathrm{mg} \mathrm{O}_{2} / \mathrm{g}$ MLSS $/ \mathrm{min}$ and $\mathrm{Ks}=1.230 \mathrm{~g} / \mathrm{l}$ glucose (Figure 4).

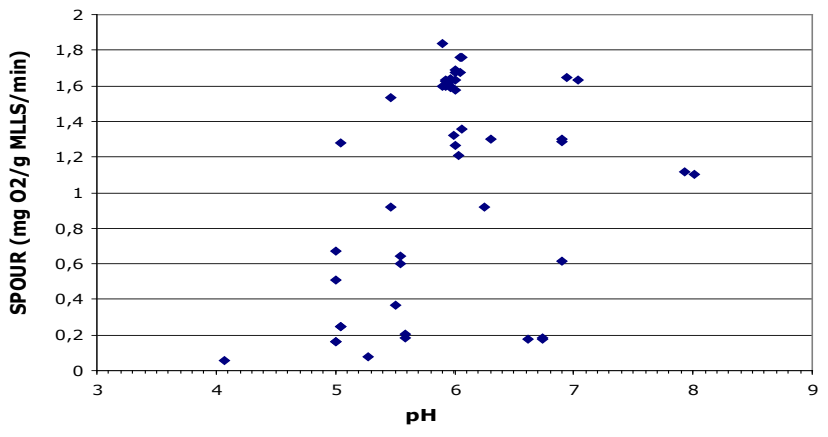

Figure 1: Variation of SPOUR as a function of reactors $\mathrm{pH}$. 


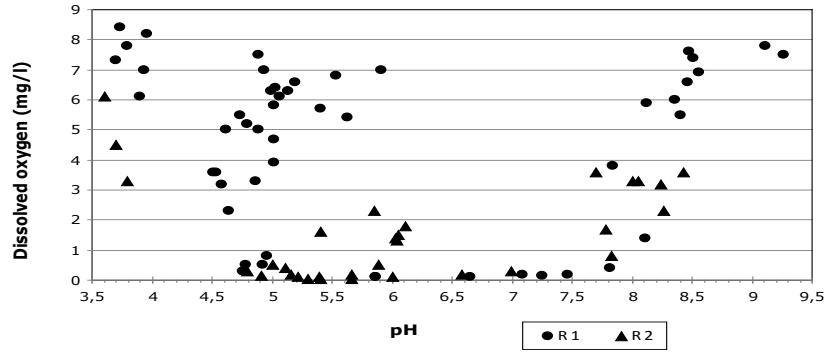

Figure 2: Relationship between $\mathrm{DO}$ and $\mathrm{pH}$ for the two reactors.

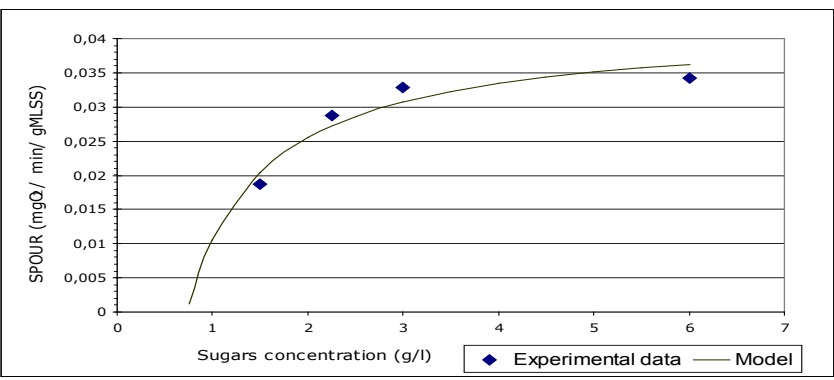

Figure 3: SPOUR obtained using a mixture of sugars as substrate.

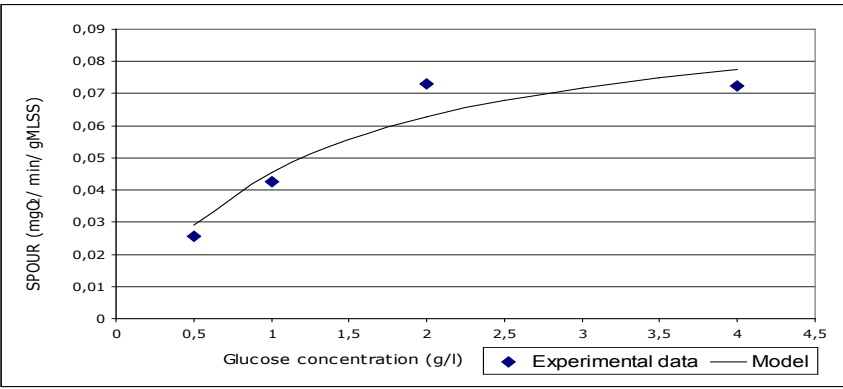

Figure 4: SPOUR obtained using glucose as substrate.

\section{Kinetics of COD degradation: influence of aeration rates}

During the first periods of reactors follow-up and even with $\mathrm{pH}$ correction, high degradation rates were obtained only when the influent contained less than $30 \mathrm{~g} / \mathrm{l}$ of COD. Consequently, the effect of aeration rate was suspected. Adamse et al. [4], showed that with dairy waste activated sludge, high aeration rates did not prevent the $\mathrm{pH}$ decrease obtained when high substrate concentration was imposed. However, restoring of the $\mathrm{pH}$ to its initial values was accelerated at high aeration rates. Thereafter, aeration rates were increased in the reactors and different influent concentrations from 50 to $80 \mathrm{~g} / \mathrm{l}$ of COD were tested, but steady-state COD elimination stayed almost constant, around $30 \mathrm{~g} / \mathrm{l}$ of COD. The $\mathrm{k}_{\mathrm{L}}$ a values obtained for the different aeration configurations tested ranged from $1.5 \times 10-3 / \mathrm{s}$ to $9.8 \times 10^{-3} / \mathrm{s}$ (Table 2).

COD degradation kinetics were also determined during the same periods using the pilots follow-up data. For each steady-state period and under given aeration conditions, obtained COD degradation rates (as g/l of COD eliminated/g MLLS/h) were expressed, and converted into concentrations that could be eliminated in the real WWTP assuming the same aeration and MWRT conditions Table 2.
For the two reactors, the COD degradation rate increased with increasing aeration rate. MWRT had no clear effect in a large interval, at least for reactor 2 which was more aerated than reactor 1 . The degradable COD concentration of the influent did never exceed $35 \mathrm{~g} / \mathrm{l}$, corresponding to a maximum allowable influent concentration of no more than $50 \mathrm{~g} / \mathrm{l}$.

The corresponding Oxygen transfer rate (OTR) in clean water was evaluated to $0.08 \mathrm{mgO} 2 / \mathrm{s} / \mathrm{l}$ for the optimum conditions of oxygenation that was near from the $0.1-0.14$ OTR value range given for the full scale WWTP aerator.

\section{Residual substrate concentration}

In order to check the degradable fraction of the influent COD, the COD obtained in the reactors was plotted against measured acids concentrations. A linear regression correlation was found for each reactor:

\section{Reactor $1: \mathrm{COD}=1.26 \mathrm{x}$ Acids concentration $+4.2 \mathrm{r}^{2}=0.85$}

Reactor 2: $\mathrm{COD}=1.17 \mathrm{x}$ Acids concentration $+6.4 \mathrm{r}^{2}=0.54$

These relations indicated that the treated wastewater presented a residual substrate concentration containing acids but also another organic fraction. This later can be associated to the protein fraction of the effluent that undergoes decomposition more slowly than the sugars [4]. The residence time used in this experiment was may be too short to obtain a good degradation of complex proteins. The higher activity obtained with reactor 2 led also to a less linear correlation.

\section{Production of organic acids intermediates}

When the reactors were fed with confectionary wastewater (batch feeding, as mentioned in Operational Procedure) DO dropped sharply after feeding and $\mathrm{pH}$ dropped more slowly (Figure 5).

The $\mathrm{pH}$ drop during the degradation of the carbohydrate fraction

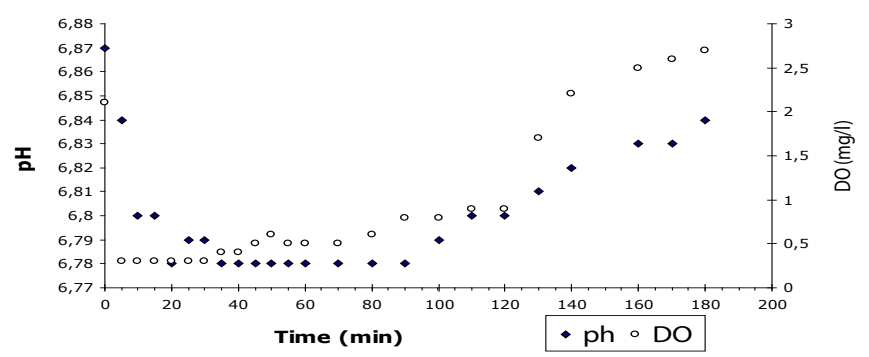

Figure 5: Evolution of $\mathrm{DO}$ and $\mathrm{pH}$ after a feed.

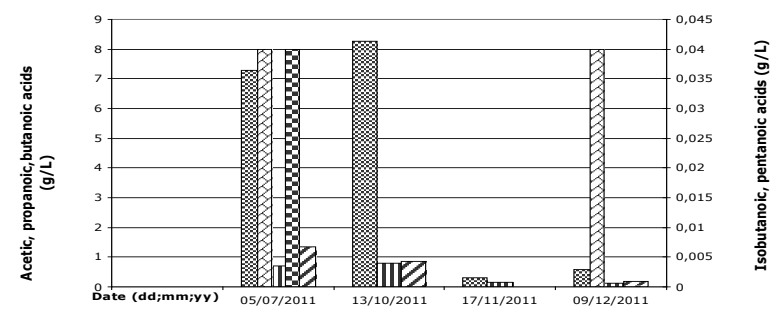

acetic II propanoic $\square$ butanoic 8 isobutanoic $\mathrm{Q}$ pentanoic

Figure 6: Main acid intermediates obtained by chromatographic analyses in the effluent of reactor 2 . 


\begin{tabular}{|c|c|c|c|c|c|c|}
\hline Reactor Number & DO & $\begin{array}{c}\mathrm{K}_{\mathrm{L}} \mathrm{a} \\
\left(\mathrm{S}^{-1}\right)\end{array}$ & $\begin{array}{c}\text { MWRT } \\
(\mathrm{d})\end{array}$ & $\begin{array}{c}\text { COD } \\
\text { Reactor }(\mathrm{gl})\end{array}$ & $\begin{array}{c}\text { COD degradation rates } \\
\text { (gCOD/ gMLSS/h) }\end{array}$ & Degradable COD in the full scale WWTP(g/l) \\
\hline 1 & Limitanat & 1.5 & 14 & 29 & 0.018 & 0.024 \\
1 & Present & N.C & 21 & 16 & 0.034 & 23 \\
1 & Present & N.C & 1.7 & 8 & 0.035 & 32.6 \\
2 & Present & 4.8 & 15 & 13.2 & 0.036 & 33.6 \\
2 & excess & 9.8 & 1 & 1.6 & 34.6 \\
\hline
\end{tabular}

Table 2: $\mathrm{K}_{\mathrm{L}}$ a and COD degradation rates obtained during the reactors follow-up.

\begin{tabular}{|c|c|c|c|c|}
\hline Reactor number & $\begin{array}{c}\text { COD } \\
\text { Reactor }(\mathrm{g} / \mathrm{l})\end{array}$ & DO & $\begin{array}{l}\text { MWRT } \\
\text { (d) }\end{array}$ & $\begin{array}{l}\text { Acids total concentration } \\
\qquad(\mathrm{g} / \mathrm{l})\end{array}$ \\
\hline $\begin{array}{l}1 \\
1 \\
2 \\
2\end{array}$ & $\begin{array}{l}25 \\
10 \\
16 \\
3.5\end{array}$ & $\begin{array}{c}\text { Limitant } \\
\text { Present } \\
\text { Present } \\
\text { Excess }\end{array}$ & $\begin{array}{l}15 \\
1.7 \\
14 \\
2.4\end{array}$ & $\begin{array}{c}17 \\
8 \\
10 \\
0.7\end{array}$ \\
\hline
\end{tabular}

Table 3: Measured total acid concentration.

\begin{tabular}{|c|c|c|c|}
\hline Transformation rates for & Substrate & $\mathbf{V}_{\text {max }}$ (g substrate/g $\left.\mathbf{M L S S}_{\mathbf{h}}\right)$ & 0.2 \\
\hline Sugars degradation & Glucose-fructose-sucrose & 0.2 & $\mathbf{K}_{\mathbf{s}}$ (g substrat) \\
\hline Acids degradation & Acetic acid & 0.09 \\
\hline
\end{tabular}

Table 4: Michaelis-Menten kinetics constants obtained for the treatment.

was caused by transitory accumulation of acid intermediates (mainly acetic, propanoic and butanoic) that were detected by HPLC and titration. This result was in accordance with those of Adamse [4] and Caunt et al. [11]. In addition, appreciable amounts of propanoic and butanoic acids were found here, accompanied by traces of pentanoic and isobutanoic acids (Figure 6).

As can be seen in Table 3, the concentration of residual organic acids increases strongly when aeration decreases, as expected. Surprisingly, at the same loading rate and dissolved oxygen concentration, a diminution of residence time in the reactor improves degradation performances, which result is in contradiction with the usual kinetics. This may be explained considering that keeping the load constant while decreasing the residence time is only possible through a dilution of the effluent, thus lowering the concentrations of sugars and acids intermediates. Acetic acid has already been reported to inhibit microorganisms activity when highly concentrated [3, 12-14], because of $\mathrm{pH}$ inhibition or of unionized acetate inhibition $[3,15]$. Here, inhibition seemed to increase with the acid concentration, and to decrease with the availability of Oxygen.

\section{Degradation rates evaluation}

The values of kinetic parameters obtained by adjustement to a Michaelis- Menten equation are summarized in Table 4. So, it can be concluded that under the high loads encountered in this study, sugars are readily transformed into acids intermediates that are released in the solution. The degradation rate for the acids being lower than their production rate, their concentration increases up to the point where the $\mathrm{pH}$ drop induces inhibition of the process. A comparison of the $\mathrm{V}_{\max }$ value for the sugars degradation and the $\mathrm{V}_{\max }$ value for Oxygen respiration in the presence of sugars found above (max. 0.1 $\mathrm{mg} \mathrm{O}_{2} / \mathrm{gMLSS}^{-1} \mathrm{~min}^{-1}=6 \mathrm{mg} \mathrm{O}_{2} / \mathrm{gMLSS}^{-1} \mathrm{~h}^{-1}$ ) confirms that direct acid production from sugars is a mechanism that proceeds with a low Oxygen consumption.

\section{Conclusions}

Although powerful aeration equipments may be used, the high load aerobic pretreatment of highly concentrated confectionary wastewaters may create very low $\mathrm{pH}$ conditions leading altogether to a decrease of COD degradation rate and severe damages to the plants.
This study demonstrated that in these conditions, a high uncontrolled production of organic acids intermediates by bacteria (mainly acetic acid but also others) occurred even with high aeration rates. The degradation rates of these acids being smaller than their production rates, their accumulation lead to the observed $\mathrm{pH}$ drop and to the further degradation inhibition and high COD residual. Classical degradation kinetics based solely upon MWRT and substrate concentration is unable to represent this phenomenon and cannot be used for the design of such WWTP.

As physico-chemical conditions were similar, a comparison between the laboratory scale pilots and the full scale plant was made by measuring in the pilots the clean water OTR and comparing its values to the values given for the WWTP.

Once this assessment done, the physico-chemical and kinetics data issuing from the study were compared to those obtained from the actual WWTP. This allowed to give the following recommendations for industrial scale-up:

1. the WWTP OTR value allows to obtain the same performances as our laboratory scale reactor, i.e. a reduction of 30 to $35 \mathrm{~g}$ COD per liter, but not to obtain an effluent in accordance with the emission standards when the influent concentration exceed $50 \mathrm{~g} / \mathrm{l}$ of COD. Any increase in OTR value would be useless as this does not increases the COD reduction.

2. keeping the $\mathrm{pH}$ of the aeration tank between 5 and 6 (around 5.5) units by using $\mathrm{NaOH}$ addition and keeping influent concentrations at no more than $45 \mathrm{~g} / \mathrm{l} \mathrm{COD}$, the existing aeration facilities, once properly protected against corrosion, would allow to obtain effluent concentrations complying with the maximum allowed value of $15 \mathrm{~g} / \mathrm{l} \mathrm{COD}$ for the outlet flow to the sewer.

\section{Acknowledgments}

This work was supported by CNRS/HARIBO Inc. Research Collaboration Agreement $\mathrm{n}^{\circ}$ CT063051s.

\section{References}

1. Orhon D, Yildiz G, Ubay Cokgör E, Sözen S (1995) Respirometric evaluation of the biodegradability of confectionay wastewaters. Water Science and Technology 32: 11-19. 
Citation: Drakides C, Lay-Son M (2013) Acid production as a Limiting Factor during the Aerobic Biological Pre-Treatment of Confectionary Wastewaters. J Civil Environ Eng 3: 128. doi:10.4172/2165-784X.1000128

2. Bertola N, Palladino L, Bevilacqua A, Zaritzky N (1999) Optimisation of the design parameters in an activated sludge system for the wastewater treatment of a potato processing plant. Journal of Food Engineering 40: 27-33.

3. Vavilin VA, Lokshina LY (1996) Modeling of volatile fatty acids degradation kinetics and evaluation of microorganism activity. Bioresource Technology 57 69-80.

4. Adasme A (1968) Response of dairy waste activated sludge to experimental conditions affecting $\mathrm{pH}$ and dissolved oxygen concentration. Water Research 2: 703-713.

5. Ugwanyi JO, Harvey LM, McNeil B (2005) Effect of aeration rate and waste load on evolution of volatile fatty acids and waste stabilization during thermophilic aerobic digestion of a model high strenght agricultural waste. Bioresour Technol 96: 721-730.

6. De Anda R, Lara AR, Hernàndez V, Hernàndez-Montalvo V, Grosset G, et al. (2006) Replacement of the glucose phosphotransferase transport system by galactose permease reduces acetate accumulation and improves process performance of Escherichia coli for recombinant protein production without impairment of growth rate. Metabolic engineering 8: 281-290.

7. Déronzier G, Duchène Ph, Héduit $A$ (1998) Optimization of oxygen transfer in clean water by fine bubble diffused air system and separate mixing in aeration ditches. Water Science and Technology 38: 35-42.
8. Duchène $P$, Cotteux $E$ (1996) Insufflation d'air fines bulles : Application aux stations d'épuration en boues activées des petites collectivités. Ministère de l'Agriculture et de la Pêche FNDAE n² 26 Document technique, $54 \mathrm{pp}$

9. Garcia-Ochoa F, Gomez E (2009) Bioreactor scale-up and oxygen transfer rate in microbial processes: An overview. Biotechnology Advances 27: 153-176.

10. Lay-Son M, Drakides C (2008) New approach to optimize operational conditions for the biological treatment of a high-strength thiocyanate and ammonium waste: $\mathrm{pH}$ as key factor. Water Research 42: 774-780.

11. Caunt $P$, Hester KW (1988) A kinetic model for volatile fatty acid biodegradation during aerobic treatment of piggery wastes. Biotechnol Bioeng 34: 126-130.

12. Van Zyl C, Prior BA, du Preez JC (1991) Acetic acid inhibition of D-xylose fermentation by Pichia stipitis. Enzyme and Microbial Technology 13: 82-86.

13. Stratford M, Plumridge A, Nebe-von-Caron G, Archer DB (2009) Inhibition of spoilage mould conidia by acetic acid and sorbic acid involves different modes of action, requiring modification of the classical weak-acid theory. Int $\mathrm{J}$ Food Microbiol 136: 37-43

14. Boltes K, Leton P, Garcia-Calvo E (2008) Volatile fatty acid anaerobic degradation: Kinetic modeling with an inoculum under controlled conditions. Industrial and Engineering Chemistry Research 47: 5337-5345.

15. Cammarota MC, Freire DMG (2006) A review on hydrolytic enzymes in the treatment of wastewater with high oil and grease content. Bioresour Techno 97: $2195-2210$ 